\title{
Edukasi komunikasi politik dalam menciptakan kesadaran dan minat pemilih perempuan
}

\author{
Nia Sarinastiti ${ }^{1}$ dan Petty S. Fatimah ${ }^{2}$ \\ ${ }^{1}$ Universitas Katolik Indonesia Atma Jaya, Jakarta, Indonesia \\ ${ }^{2}$ Femina - Prana Group, Jakarta, Indonesia
}

\begin{abstract}
ABSTRAK
Tujuan penelitian ini adalah untuk mengetahui bagaimana perempuan melihat dan berpartisipasi dalam dinamika politik di Indonesia saat ini. Konsep yang mendasari penelitian adalah sosialisasi politik, partisipasi publik, preferensi dan kesetaraan gender karena di dalam menentukan preferensi seharusnya mendapatkan edukasi publik sehingga akhirnya menentukan tingkat partisipasi individu, dalam hal ini perempuan. Metode penelitian dilaksanakan secara mixed methods melalui survei, Focus Group Discussion (FGD) dan wawancara. Penentuan kategori adalah untuk melihat apakah terdapat perbedaan juga terhadap pengalaman dan preferensi pada kedua kelompok pemilih ini yang terkait pula pada perbedaan kelompok usia. Penyebaran survei dilakukan sebelum PILKADA 28 Juni secara online dengan menyertakan link pada website dan media sosial tertentu. Hasil sampling melalui penyebaran tersebut menghasilkan sejumlah 1,580 responden. Sedangkan untuk FGD dilaksanakan setelah berlangsungnya PILKADA, dengan tujuan untuk mengkonfirmasi temuan bagaimana para perempuan memahami program para kandidat, bagaimana minat muncul pada waktu PILKADA dan mengapa akhirnya memilih. Hasil analisis matriks menunjukkan bahwa banyak pemilih yang kurang terinformasi, padahal memiliki minat. Selain itu, minat perempuan memilih didasarkan pada keinginan menjalankan hak pilihnya dan minat pemilih didasarkan pada pemahaman terhadap rekam jejak calon melalui media online, televisi dan media sosial. Walau demikian masih ada kelompok pemilih perempuan lebih mengenal calon dari lingkungan keluarga, spanduk/ baliho, koran, dan dari materi Komisi Pemilihan Umum. Sedangkan preferensi yang muncul untuk sifat pemimpin adalah jujur dan berintegritas, mempunyai pengalaman memimpin dan tegas, dan kedekatan dengan masyarakat.
\end{abstract}

Kata-kata Kunci: edukasi publik; partisipasi; pemilih perempuan; preferensi publik; sosialisasi politik

\section{Political communication education to create awareness and interest of women voters}

\begin{abstract}
The purpose of this research is to see how women join and participate in the political dynamics of Indonesia today. The concepts underlying the research are political socialization, public participation, preference, and gender equality. In determining preferences, a person should at least have public education, which ultimately determines the level of individual participation especially, women. The research uses mixed methods through survey, Focus Group Discussion (FGD), and interviews. The survey is conducted on-line using links through websites and social media prior to the June 28 election, consists of total 1,580 respondents. FGD is carried out after the Regional Election took place, with the aim of confirming the findings of how the women understood the candidates' programs, how interests emerged at the time of the election, and why they finally vote. Interviews are conducted to verify the data from respondents. Based on the matrix analysis, it indicates that many voters are less informed, even though they have an interest in politics. In addition, women's interest in choosing is based on the desire to exercise their voting rights, and voter interest is based on an understanding of the candidate's track record through on-line media, television and social media. Even so, there are still groups of women voters who know more about candidates from the family environment, banners/billboards, newspapers, and from the General Election Commission's material. Whereas the emerging preference for the nature of the leader is honest and integrity, has a leading and decisive experience, and close to community.
\end{abstract}

Keywords: female voters; participation; political socialization; public preference; public education

Korespondensi: Dr. Nia Sarinastiti M.A, UNIKA Atma Jaya - Jakarta, Gedung C. 1t 1, Jl. Jend. Sudirman No.51, Karet Semanggi, Kecamatan Setiabudi, Kota Jakarta Selatan, DKI 12930.Email: nia.sarinastiti@, atmajaya.ac.id

Submitted: October 2018, Accepted: April 2019, Published: June 2019

ISSN: 2303-2006 (print), ISSN: 2477-5606 (online). Website: http://jurnal.unpad.ac.id/jkk

Terakreditasi Kemenristekdikti RI SK No. 48a/E/KPT/2017 


\section{PENDAHULUAN}

Pesta demokrasi PILKADA 2018 pada 28 Juni telah sukses terlaksana. Menurut Ketua Komisi Pemilihan Umum (KPU), Arief Budiman, terdapat 158 juta pemilih yang berpartisipasi pada PILKADA 2018, hampir $80 \%$ dari total pemilih nasional. Walau pada akhirnya Komisi KPU menyatakan tingkat partisipasi pemilih pada PILKADA Serentak 2018 sebanyak 73,24\% dari total daftar pemilih tetap sebanyak 152 juta orang, tingkat partisipasi wanita merupakan yang tertinggi, mencapai $76.67 \%$. Sedangkan untuk pemilih laki-laki sebanyak 69.32\% (Ihsanuddin, 2018).

Dengan jumlah pemilih perempuan yang cukup besar tersebut, maka yang menjadi dasar pertimbangan seseorang dalam menentukan pilihannya menjadi sebuah pertanyaan. Majalah Femina menyitir Ani Soetjipto - dosen FISIP Universitas Indonesia, yang sudah lama bergiat dalam partisipasi wanita dalam politik, bahwa preferensi (selera) pemilih dalam pemilu (termasuk PILKADA) banyak yang memengaruhinya dengan berbagai macam alasan dan faktor (Pratiwi, 2018).

Sedangkan menurut Achen \& Bartels (2017) tentang mengapa perilaku pemilih itu sangat tidak menentu dan tidak koheren, mengatakan sebagai berikut:

I think people are doing the best they can. They just don't have a lot of information, and so they substitute guesses and views of the world that make them feel comfortable. I think people are looking for ways to make sense of what is a very complicated reality out there. It's hard for those of us who get paid to think about it all the time to make sense of it, and it's very hard for people with a lot of other demands in their lives.

masyarakat berusaha sebaik mungkin untuk melakukan pilihan, masalahnya mereka tidak mendapatkan informasi yang banyak dan bahwa minat pada politik bukan sesuatu hal yang mudah, karena bagi yang dibayar untuk memahami politik pun sebetulnya susah. Bila tidak mendapatkan informasi, maka akan disubstitusi dengan menebak-nebak dan mencari yang nyaman untuk mereka. Sehingga dampaknya adalah kesalahan pemahaman. menegaskan bahwa bila berhubungan dengan luaran politik, sebagian besar orang tidak menggunakan keputusan rasional berdasarkan dampak kehidupan, karena pada prinsipnya pemilih memang tidak tahu. Hal ini tentu saja menjadi hal yang disayangkan karena hanya akan memilih berdasarkan perasaan sesaat, dan dapat berubah saat pemilihan terjadi (swing) (Achen \& Bartels, 2017).

Hal ini juga terjadi di Indonesia, upayaupaya dari pemerintah atau partai untuk meningkatkan pengetahuan dari para pemilih sangat penting agar calon pemilih tidak bimbang dengan pilihan calon pemimpin. Contohnya, Pemerintah Indonesia sejak akhir tahun 2014 mengatakan akan memprioritaskan pendidikan politik bagi perempuan demi meningkatkan partisipasi perempuan dalam dunia politik di Indonesia. Seperti disampaikan oleh Deputi Pengarusutamaan Gender (PUG) pada Kementerian Pemberdayaan Perempuan dan Perlindungan Anak, Heru Prasetyo Kasidi (Samosir, 2014), bahwa pendidikan politik perempuan di pelosok Indonesia tetap menjadi perhatian utama pemerintah. Dengan keputusan tersebut, perempuan memiliki kesempatan yang sama, bukan hanya dalam memilih, namun juga untuk mendapatkan informasi, atau bahkan pendidikan politik. Apakah Indonesia memiliki potensi untuk itu?

Secara kependudukan berdasarkan estimasi Sensus Penduduk Indonesia, jumlah perempuan di Indonesia cukup signifikan yaitu 49.7\% (atau sebanyak 132,5juta) dari 266,5 juta jumlah populasi Indonesia tahun 2018. Selain itu, Data KPU menyebutkan bahwa Daftar Penduduk Pemilih Pemilihan (DP4) PILKADA serentak 2018 hasil perhitungan KPU menyentuh angka 152 lebih jiwa, yang terdiri dari laki laki 75.975.607 pemilih dan perempuan 76.081.447 pemilih (Nadlir, 2018).

Dengan jumlah signifikan tersebut suara perempuan (seharusnya) juga signifikan dalam pemilihan politik. Akan tetapi, menurut pengamatan Jurnal Perempuan (Pratiwi, 2018), optimisme terhadap kemungkinan perempuan untuk memilih sangat sedikit, karena banyak dipengaruhi oleh lingkungan mereka - dari segi budaya dan agama - sehingga persentase pemilih perempuan yang peduli pada kesetaraan gender juga kecil.

Merupakan hal yang menarik untuk melihat bagaimana pemilih melihat para calon 
perempuan pemimpin ini dengan mengambil contoh kasus pada pemilihan Gubernur Jawa Timur pada PILKADA serentak 2018 lalu. Dua calon gubernur sama-sama sepasang laki-laki dan perempuan: Syaifullah Yusuf (Gus Ipul) - Puti Guntur Soekarno dan Khofifah Indar Parawansa - Emil E Dardak. Setiawan (2018) memaparkan bahwa kedua pasangan ini relatif memiliki rekam jejak yang baik sebagai birokrat. Syaifullah Yusuf menjabat Wakil Gubernur pada masa pemerintahan Gubernur Sukarwo (Pak De Karwo), Khofifah Indar Parwansa adalah mantan Menteri Sosial, Emil E Dardak adalah Bupati Trenggalek dan Puti Guntur adalah anggota DPR dari PDIP. Ketika Gus Ipul dihadapkan dengan Khofifah, masyarakat Jawa Timur ternyata 'berani' memilih pemimpin perempuan. Menurut analisis Kompas.com, salah satu kunci kemenangan Khofifah dalam PILKADA Jatim, imbuh Adjie, adalah bahwa dia secara personal kuat di basis Nahdlatul Ulama (NU). Selain itu, menurut Peneliti LSI Denny JA Adjie, keunggulan Khofifah juga secara gender, yakni pada basis pemilih perempuan yang memiliki kecenderungan lebih loyal (Setiawan, 2018). Dalam hal ini pemilih perempuan di Jawa Timur dinilai punya suara yang kuat dalam menentukan kemenangan Khofifah. Akan halnya Puti Guntur Soekarno, politisi muda dari PDIP yang merupakan cucu Presiden Soekarno itu dinilai tidak punya darah NU, tidak punya basis massa, juga tidak punya rekam jejak sebagai birokrat. Sehingga dianggap bahwa keberadaannya tidak mampu mendongkrak posisi Gus Ipul. Apa yang kita lihat di Jawa Timur dapat menjadi modal yang baik untuk membangun kesetaraan perempuan dan laki-laki dalam politik. Sejalan dengan terdidiknya para calon pemilih, banyak yang berpendapat bahwa kesempatan perempuan untuk menjadi pemimpin seharusnya semakin terbuka lebar. Apakah demikian?

Konsep yang mendasaripenelitian ini adalah sosialisasi politik, pengaruh media, partisipasi publik, preferensi dan kesetaraan gender, karena di dalam menentukan preferensi seharusnya mendapatkan edukasi publik sehingga akhirnya menentukan tingkat partisipasi individu. Berpartisipasi dan memberikan suara di politik merupakan hak dan kewajiban dari warga. Dalam masyarakat demokratis, keberhasilan dunia politik sebagian besar tergantung pada tindakan suka rela (volunteer) dari setiap individu warga masyarakat (Broide, 1998). Dalam politik salah satu kegiatan partisipasi penting adalah memilih - satu tindakan sehari yang membutuhkan waktu untuk memahami calon pemimpin yang akan dipilih, untuk dapat membentuk pemerintahan yang tepat. Maka pekerjaan politik dianggap berhasil bila dapat bekerja sama di tingkat komunitas - dari teman, tetangga, dan penduduk di lingkungannya secara teratur. Broide (1998) melanjutkan, sasaran paling tepat untuk menjadi partisipan adalah generasi muda -- mereka yang akan memasuki dunia politik -- antara lain pemilih pemula, para perempuan, dan minoritas yang mungkin jarang dianggap memiliki peran. Padahal justru mereka ini lebih memungkinkan untuk diberikan edukasi tentang politik, dan belum terpengaruh oleh vested interest.

Di era yang lebih menekankan pada partisipasi, kesertaan sebagai warga negara bukanlah didasari pada faktor genetik, namun harus dipelajari (Perloff, 2010). Vitalitas dan kontinuitas demokrasi sangat tergantung pada bagaimana isu-isu ditransmisikan ke tiap generasi muda, bagaimana visi sebuah kehidupan demokratis dan memberikan komitmen untuk menjalankannya (Perloff, 2010). Hal ini disebut sebagai sosialisasi politik yang didefinisikan sebagai cara bagaimana masyarakat menyampaikan orientasi politiknya - pengetahuan, tingkah laku, atau budaya dan nilai-nilai - yang disampaikan dari generasi ke generasi. Dua tema utama yang muncul dalam sosialisasi politik, yaitu kelanjutan dan perubahan (Perloff, 2015). Kelanjutan menggambarkan apa yang diperoleh saat muda cenderung akan menetap dalam kehidupan kita. Sedangkan sikap terbentuk melalui proses pengalaman makro (misal: masalah nasional seperti perang, protes politik, bencana di masa kecil dan remaja membentuk sikap) dan mikro (misal: keterikatan politik tersusun dari pandangan orang tua atau agen berpengaruh). Pada intinya, konsep ilmu sosial berusaha menjelaskan bagaimana sikap politik terbentuk di masa muda akan berlanjut dalam waktu tertentu.

Maka dengan hal itu, merupakan hal esensial bahwa sosialisasi politik menjadi salah satu alasan untuk berpartisipasi dalam politik. Pada awalnya, sebagian besar masyarakat terlibat dalam proses politik dengan hanya muncul di tempat pemilihan untuk memilih, 
dan tidak pernah berpartisipasi dalam aktivitas kampanye ataupun dalam dialog yang dilakukan sebelumnya.

Politik saat ini telah mengalami banyak perubahan dengan adanya kecepatan dan keteguhan politik modern. Walau sumber informasi konvensional seperti, radio FM, televisi, dan film yang didistribusikan secara luas telah mengubah cara orang memperoleh informasi, menyebarkan dan mengembangkan pengetahuan tentang dunia di sekitar mereka, namun kini, lingkungan telah berubah lagi melalui inovasi digital. Para pemilih sekarang ini dapat menonton berita kabel, me-retweet posting politik, atau menerima pemberitahuan berita via telepon, email, dan media sosial. Komunikasi politik kini terjadi secara terusmenerus dan secara real time sehingga harus selalu dapat memonitor dengan cepat, memanfaatkan big data, dan melakukan penenelitian respons/opini berkelanjutan (Schill \& Kirk, 2014). Metode penelitian tradisional sering tidak menangkap lingkungan yang dinamis ini. Upaya menggunakan big data untuk melihat respons secara cepat merupakan cara yang diupayakan oleh beberapa pusat studi/ polling saat pemilihan calon pemimpin terjadi.

Selain itu, berkembangnya Internet, hambatan komunikasi politik telah terpatahkan dan identifikasi dengan partai politik menjadi berubah (Evins, 2016). Hal ini karena individu menunjukkan pemanfaatan layar kedua (second screen experience) dalam melakukan pengamatan terhadap proses politik melalui media sosial secara 'real time'. Para pemilih baik yang berulang/ lanjut maupun yang baru mengikuti dan berinteraksi dengan para kandidat atau pejabat terpilih melalui Facebook atau Twitter. Berdasarkan penelitian, perilaku para pemilih dalam menanggapi secara langsung kegiatan-kegiatan politik dan berita terkini merupakan "hyper-voter", yaitu mereka yang kemungkinan akan terlibat dalam proses politik, antara lain untuk mendorong pihak lain untuk memilih, atau hadir pada suatu pertemuan atau peristiwa (Nee, Shen \& Dozier, 2017). Para pemilih ini akan menentukan keberadaan para kandidat di media sosial, pada saat akan memilih. Mereka ini dianggap telah 'masuk', dapat mempengaruhi, dan bersifat responsif.

Teori media sebelumnya berasumsi bahwa pemilih akan menggunakan satu medium di antarayangbanyakuntukmendapatkan perhatian (televisi, koran, radio, dan sebagainya) (Nee, Shen \& Dozier, 2017). Dengan meningkatnya pengalaman layar kedua, penggunaan satu medium bukanlah keadaan yang sekarang. Media sosial saat ini adalah media dengan respons tercepat, yang memberikan kesempatan dalam menghubungkan diri mereka dengan para politisi mendekati 'real-time'. Seperti diketahui, terdapat hubungan yang erat antara konten media massa dan peningkatan partisipasi politik dari warga sipil. Diharapkan, pengalaman pengguna layar kedua ini dapat meningkatkan perilaku untuk memilih, terutama bagi generasi pemilih pemula, mengingat bahwa jeda waktu pengiriman dan penerimaan informasi sangat sedikit.

Keterlibatan perempuan dalam politik juga dapat dilihat dengan konsep kesetaraan gender dalam politik yang mengacu pada World Economic Forum Gender Report 2018 (WEFGR). Dibandingkan dengan Laporan dalam UNDP Human Development Report (HDR) (UNDP, 2016) -- yang hanya menilai dari sudut Gender Inequality dalam politik dari jumlah kursi di parlemen dan jumlah menteri di pemerintahan, WEFGR melihat kesetaraan gender di bidang politik dari beragam faktor. Bila HDR menempatkan Indonesia pada peringkat 113, WEFGR melaporkan bahwa Index Indonesia berada di peringkat 85 dari 144 negara. Dengan peringkat 85 tersebut, Indonesia memiliki celah yang lebih lebar terkait anggota parlemen, pimpinan tertinggi dan manajer, namun terjadi penyempitan celah terkait pekerja profesional dan teknis, serta peningkatan upah kerja dan kompensasi. Walau demikian, untuk spesifik bidang political empowerment, Indonesia berada di peringkat 60 - yang berarti di atas Cina (78) dan Amerika Serikat (98) - karena partisipasi perempuan di ranah kepartaian, parlemen, pemerintahan, dan pimpinan negara tertinggi lebih tinggi dibandingkan kedua negara tersebut. Akan tetapi masih sangat berada di bawah India (19) dan negara tetangga Australia (49). Namun hal yang penting untuk dilihat adalah bahwa faktorfaktor kesetaraan gender secara keseluruhan sebenarnya memengaruhi satu sama lain. Misalnya dalam lingkup politik, aktivitas perempuan di ranah publik memberikan dampak positif pada ketidaksetaraan di publik secara umum. Masalah-masalah yang menjadi topik advokasi, prioritisasi, dan investasi 
memberikan implikasi pada kehidupan sosial masyarakat (kesehatan, pendidikan, dan kehidupan berkeluarga). Menurut Organization for Economic Co-operation and Development (OECD) (World Economic Forum, 2016), keterlibatan perempuan dalam kehidupan publik menunjukan dapat memberikan kredibilitas yang lebih baik untuk institusinya dan menunjukan keluaran demokratis. Di samping itu, terdapat banyak bukti bahwa pimpinan politik perempuan dan partisipasi ekonomi saling berhubungan.

Dengan demikian, dasar kerangka pemikiran dalam penelitian ini adalah pemilih perempuan dapat meningkatkan keterlibatannya dalam politik bila memiliki informasi yang layak dari beragam medium yang tersedia sebagai referensi dalam menentukan pilihan calon pemimpinnya, sehingga diharapkan dapat menentukan minat atau ketertarikan dalam memilih.

Terkait dengan latar belakang tersebut, maka pemahaman akan calon pemimpin yang akan dipilih merupakan faktor penting di dalam menentukan suara bagi perempuan. Dalam sudut angka pemilih, memang suara perempuan seharusnya memberikan dampak signifikan terhadap pilihan pimpinan di daerah mereka. Namun bila pilihan didorong oleh faktor kesamaan agama, pengaruh keluarga atau bagian dari dinasti politik seperti yang disampaikan oleh Soetjipto di atas, maka signifikansi menjadi tidak relevan.

Seperti yang disampaikan oleh Jurnal Perempuan, optimisme terhadap kemungkinan perempuan memilih sangat sedikit, sehingga persentase pemilih perempuan yang peduli pada kesetaraan gender juga kecil. Akan tetapi, dengan pesimisme keikutsertaan perempuan dalam PILKADA, juga berdampak pada hasil pilihan dari pimpinan yang terpilih. Maka dengan itu penelitian tentang bagaimana pandangan perempuan dalam hal politik, terutama PILKADA, dan dorongan apakah yang mempengaruhi partisipasi dalam kegiatan politik saat PILKADA merupakan daya tarik para peneliti. Lebih jauh lagi terdapat keinginan untuk melihat apakah pilihan yang bersifat primordial (kesukuan, kesamaan agama, kedaerahan) menjadi preferensi para perempuan pemilih, ataukah terdapat faktor lain yang lebih mempengaruhi, sebagaimana disebut oleh Widyastuti di atas, terkait pengalaman dari para calon pemimpin. Namun yang terpenting dari penelitian ini adalah informasi apa, dan bagaimana preferensi perolehan informasi terjadi tentang calon pemimpin di daerah yang dapat menjadi referensi terhadap pandangan yang diberikan oleh calon pemilih (pemula dan pemilih lanjut).

Sehubungan dengan hal tersebut, maka pertanyaan penelitiannya adalah: "Bagaimana preferensi perempuan dalam memilih dan bagaimana memperoleh informasi tentang calon pemimpin mereka?". Sedangkan tujuan penelitian ini adalah untuk mengetahui preferensi perempuan dalam memilih calon pemimpin mereka, dan bagaimana memperoleh informasi tentang calon pemimpin mereka, sehingga mendapatkan referensi yang layak untuk berpartisipasi dalam dinamika politik di Indonesia saat ini. Penelitian ini melihat juga pada kecenderungan perbedaan dan persamaan antara pemilih pemula (first time voter) dan pemilih yang telah/pernah memilih (pemilih lanjut).

\section{METODE PENELITIAN}

Konsep-konsep yang telah disebutkan di bagian pendahuluan mendasari kerja sama tripartiad antara Femina, Jurnal Perempuan dan Accenture untuk melaksanakan penelitian bersama. Ketiga pihak ini peduli dengan konsep kesetaraan gender, baik dari lingkup rumah tangga hingga kepentingan sosial, ekonomi, dan politik. Bagi Accenture, sebagai perusahaan konsultan skala global, melihat bahwa peranan perempuan dari berbagai berprofesi untuk memilih, dan dalam memberikan berpendapat merupakan hal yang menarik untuk diteliti dan dipahami. Sedangkan bagi Femina dan Jurnal Perempuan, pandangan mereka adalah bahwa belum terpenuhinya keadilan gender dalam dunia politik karena perempuan masih dijadikan sebagai kelompok yang termarjinalkan. Peneliti utama merupakan pihak yang melakukan paparan penelitian dan menganalisis hasil perolehan data.

Metode penelitian ini bersifat deskriptif untuk menggambarkan secara detil suatu objek atau fenomena sosial yang diamati (Eriyanto, 2014). Sedangkan Metode penelitian dilaksanakan secara mixed methods melalui survei, Focus Group Discussion (FGD), dan wawancara. Berdasarkan prioritas, maka 
dipergunakan penelitian kuantitatif dengan urutan (sequence) untuk berikutnya adalah kualitatif. Cara ini menurut Bryman (2016), adalah desain penelitian yang menggunakan explanatory sequential.

Untuk survei, ditentukan populasi adalah perempuan Indonesia, urban (tinggal di kota besar), berusia 15 tahun ke atas, dari kelas sosial menengah (SES A \& B) yang memiliki akses Internet, yang terbagi atas dua kategori, yaitu perempuan yang telah pernah memilih (pemilih lanjut), dan perempuan pemilih pemula/first time voter. Penentuan kategori adalah untuk melihat apakah terdapat juga perbedaan terhadap pengalaman dan preferensi. Penyebaran survei dilakukan pra PILKADA 28 Juni secara online melalui website dan media sosial tertentu yang tertaut ke Surveytrix. Hasil sampling diperoleh melalui penyebaran convenience dengan menggunakan medium online menghasilkan sejumlah 1,580 responden. Sedangkan untuk FGD dilaksanakan setelah PILKADA berlangsung dengan tujuan untuk mengkonfirmasi temuan bagaimana para perempuan memahami program para kandidat, bagaimana minat muncul pada waktu PILKADA dan mengapa akhirnya memilih. Nara sumber FGD dipilih berdasarkan penentuan kriteria Jurnal Perempuan dan dilaksanakan pada 13 Agustus 2018. Adapun para pesertanya terdiri dari perwakilan dari berbagai organisasi nirlaba yaitu: Jakarta Feminist Discussion Forum, Komunitas Perempuan Peduli, Sekretariat Koalisi Perempuan Indonesia; FISIP Universitas Indonesia, dan Cakra Wikara Indonesia.

\section{HASIL DAN PEMBAHASAN}

Walau observasi Jurnal Penelitian pesimis, sebaliknya hasil penelitian ini menggambarkan optimisme. Mayoritas responden (95\%) menyatakan akan menggunakan hak pilihnya. Dan hasil ini merata baik pada kelompok responden yang sudah pernah memilih maupun responden yang akan memilih pertama kalinya (first time voter). Responden yang menjawab tidak menggunakan hak pilih, maka alasan yang diberikan bukan pada apatisme mereka pada kegiatan memilih namun lebih pada soal teknis penyelenggaraan pemilu yaitu: karena daftar pemilih yang tidak akurat dan kurangnya sosialisasi dan informasi tentang PILKADA itu sendiri selain politik uang. Mayoritas responden menyatakan sangat antusias $(25 \%)$ dan antusias (34\%) terhadap kegiatan Pilkada/Pemilu, salah satunya dengan mengikuti secara aktif menonton dan membaca semua program para calon (hampir 89\%). Antusiasme menggunakan hak pilih ini karena dua alasan utama: menyadari kewajiban sebagai warganegara dan ingin ada perubahan. Hal yang menarik, terdapat perbedaan di antara kedua kelompok responden (yang sudah pernah memilih dan pertama kali memilih/first time voter). Untuk first time voter responden yang menjawab "kewajiban sebagai warganegara" lebih besar (79\%) daripada yang menjawab "Ingin ada perubahan" (63\%). Sebaliknya pada kelompok pemilih lanjut, jawaban "Ingin ada perubahan (71\%) lebih besar dibandingkan yang memilih jawaban "Kewajban sebagai Warganegara" (67\%). Hal ini sejalan dengan hasil pada pertanyaan lainnya mengenai tingkat kepuasan terhadap pemimpin politik (daerah) yang bagi pemilih lanjut yang sudah merasakan minimal satu periode masa kepemimpinan seorang pemimpin di daerahnya. Kelompok ini lebih realistis melihat PILKADA. Pada responden yang mengaku tidak puas, ketidaksesuaian janji kampanye dan kinerja saat menjabat menjadi jawaban mayoritas (lebih dari 50\%).

Mengenai pilihan menyangkut gender tentang perempuan pemimpin dan laki-laki pemimpin, mayoritas responden (yang ke semuanya perempuan) mengatakan tidak masalah jika dipimpin laki-laki atau perempuan atau sama saja (72\%). Memilih perempuan pemimpin karena responden mendukung keterwakilan perempuan di dunia politik (82\%), perempuan dinilai lebih kuat $(20 \%)$ dan lebih jujur (26\%). Sedangkan laki-laki pemimpin dipilih karena pria lebih leluasa bergerak/ mobilitas (56\%), lebih rasional (52\%) dan lebih berwibawa (45\%). Namun masih cukup banyak responden (lebih dari 20\%) yang menyatakan akan lebih memilih pria dibandingkan perempuan jika kedua pilihan ini tersedia dengan alasan laki-laki adalah iman dan sesuai dengan ajaran agama yang dianutnya (Islam). Pelibatan perempuan dalam perencanaan kebijakan dan pembangunan belum merupakan alasan signifikan responden dalam memilih calon pemimpinnya. Tiga besar pilihan responden tentang kinerja yang diharapkan dari calon pemimpinnya adalah: Akses pendidikan lebih baik, akses kesehatan lebih baik dan keamanan. 


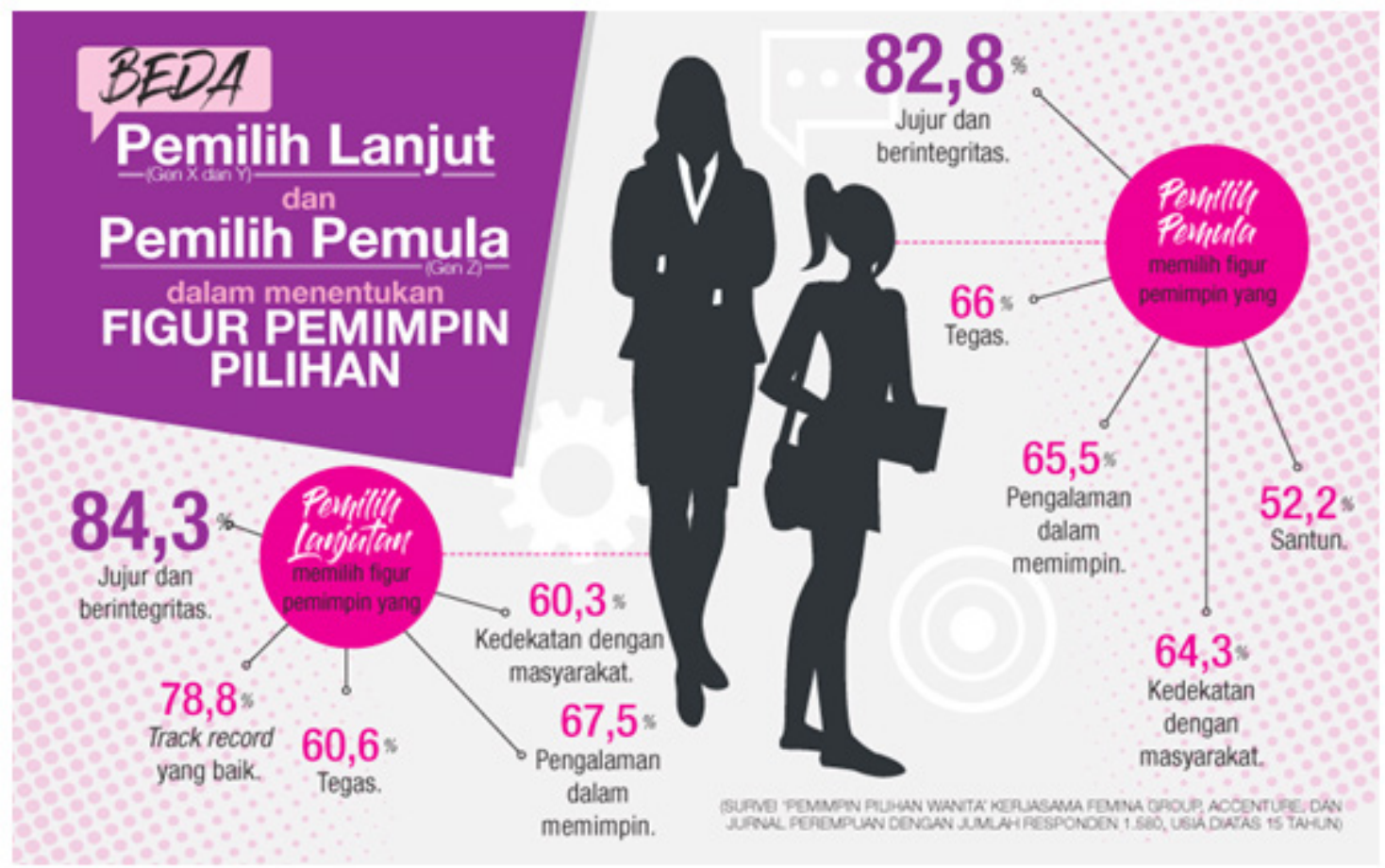

Sumber: Analisis Femina, 2018

Gambar 1 Preferensi Pemilih Pemilih Lanjutan dan Pemilih Pemula

Dari survei yang bertujuan untuk melihat sosok pemimpin ideal di mata wanita dan bagaimana wanita melihat dinamika politik di Indonesia ini juga mengangkat fakta menarik tentang perbedaan pemilih lanjut dan pemilih pemula (first voter) dalam menentukan figur pemimpin ideal mereka. Pemilih lanjut dalam hal ini bisa dikategorikan sebagai generasi $\mathrm{X}$ dan Y, memilih figur pemimpin melihat lima hal berikut yaitu jujur dan berintegritas $(84,3 \%)$, memiliki track record yang baik $(78,8 \%)$, pengalaman memimpin $(67,5 \%)$, tegas $(60,6 \%)$, dan dekat dengan masyarakat $(60,3 \%)$.

Bagi first voter, yang masuk dalam generasi $Z$, kejujuran dan integritas juga menjadi point penting dalam memilih figur pemimpin. Sekitar $82,8 \%$ responden memilih hal ini. Namun di sisi lain, mereka juga menginginkan pemimpin dengan figur yang tegas $(66 \%)$, memiliki pengalaman memimpin $(65,5 \%)$, kedekatan dengan masyarakat $(64,3 \%)$ dan santun $(52,2 \%)$.

Terkait preferensi pemimpin, penampilan bukan lagi menjadi alasan wanita memilih sosok pemimpin. Bahkan dalam survei ini, penampilan yang menarik menduduki peringkat terbawah, yang hanya dipilih oleh $11 \%$ pemilih lanjut dan $11,5 \%$ pemilih pemula. Begitu pula dengan sosok pemimpin yang mengedepankan jargon mendukung kemajuan wanita, ternyata ini bukan lagi gimmick yang menarik bagi para wanita baik dari pemilih lanjut maupun pemilih pemula, untuk memberikan suara mereka. Selain itu, para pemilih first voter terlihat lebih religius. Sekitar 51,9\% responden memilih sosok pemimpin yang beriman. Sedangkan pemilih lanjut hanya $35,8 \%$ responden saja yang mempertimbangkan faktor beriman dalam memilih figur pemimpin.

Terkat dengan ragam perolehan informasi tentang calon pemimpin, berdasarkan Gambar 2 , setengah dari responden (52\%) mengetahui sedikit mengenai para calon pemimpin mereka, sedangkan lebih dari 1/3 (36\%) responden mengetahui calon dengan jelas, $10 \%$ sama sekali tidak mengenal. Dari sudut generasi, lebih dari setengah (54\%) dari generasi $\mathrm{Y}+\mathrm{Z}$ hanya sedikit mengenal calon pemimpin mereka, dibandingkan dengan senior mereka (generasi X). Hal ini memungkinkan terjadi karena sebelumnya belum pernah memilih atau merupakan first time voters. Walau penelitian ini tidak secara spesifik meminta apa yang diketahui tentang pimpinan mereka, dapat terlihat bahwa hal ini karena pengalaman bahwa mereka baru akan memilih, yaitu generasi $\mathrm{Z}$ sebesar $67 \%$ dari responden. 

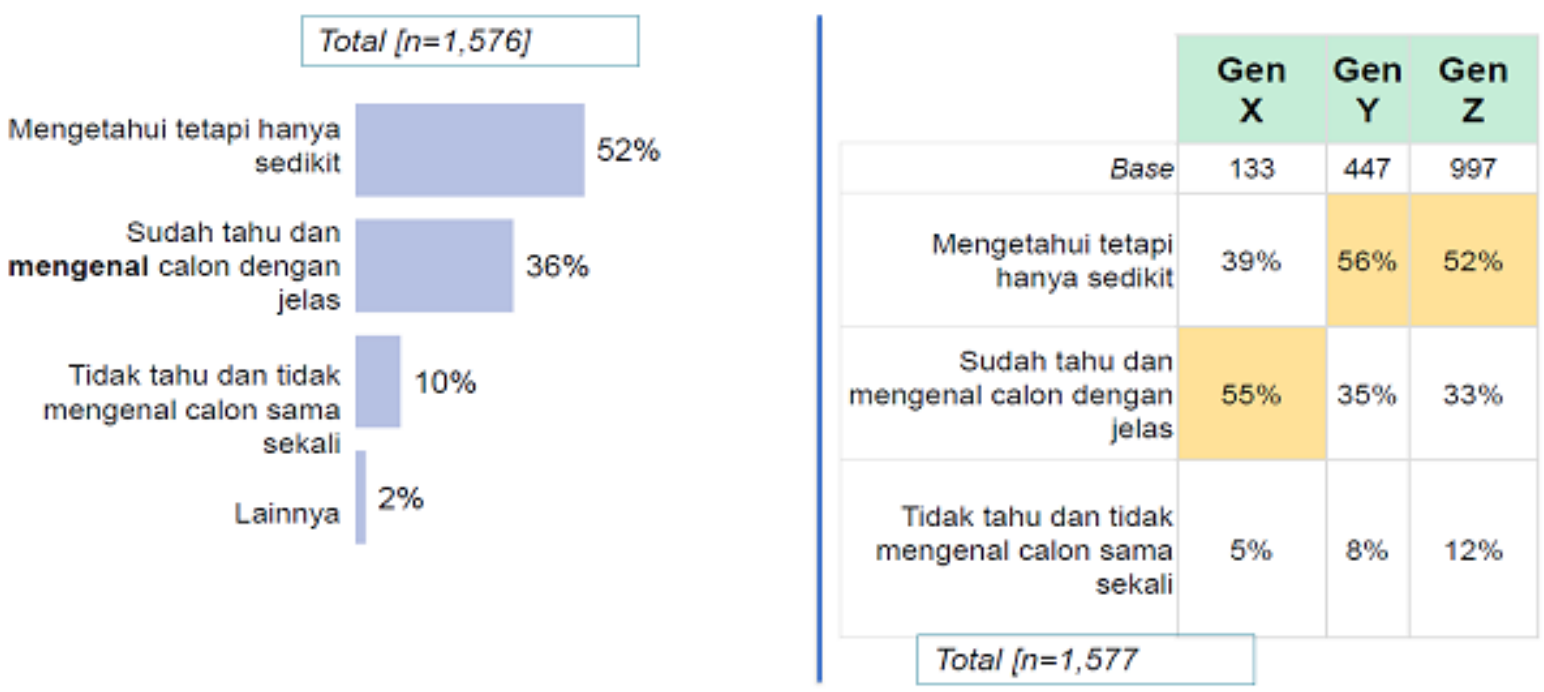

Sumber: analisis Femina, 2018

\section{Gambar 2 Pemahaman Responden terhadap Calon Pemimpin}

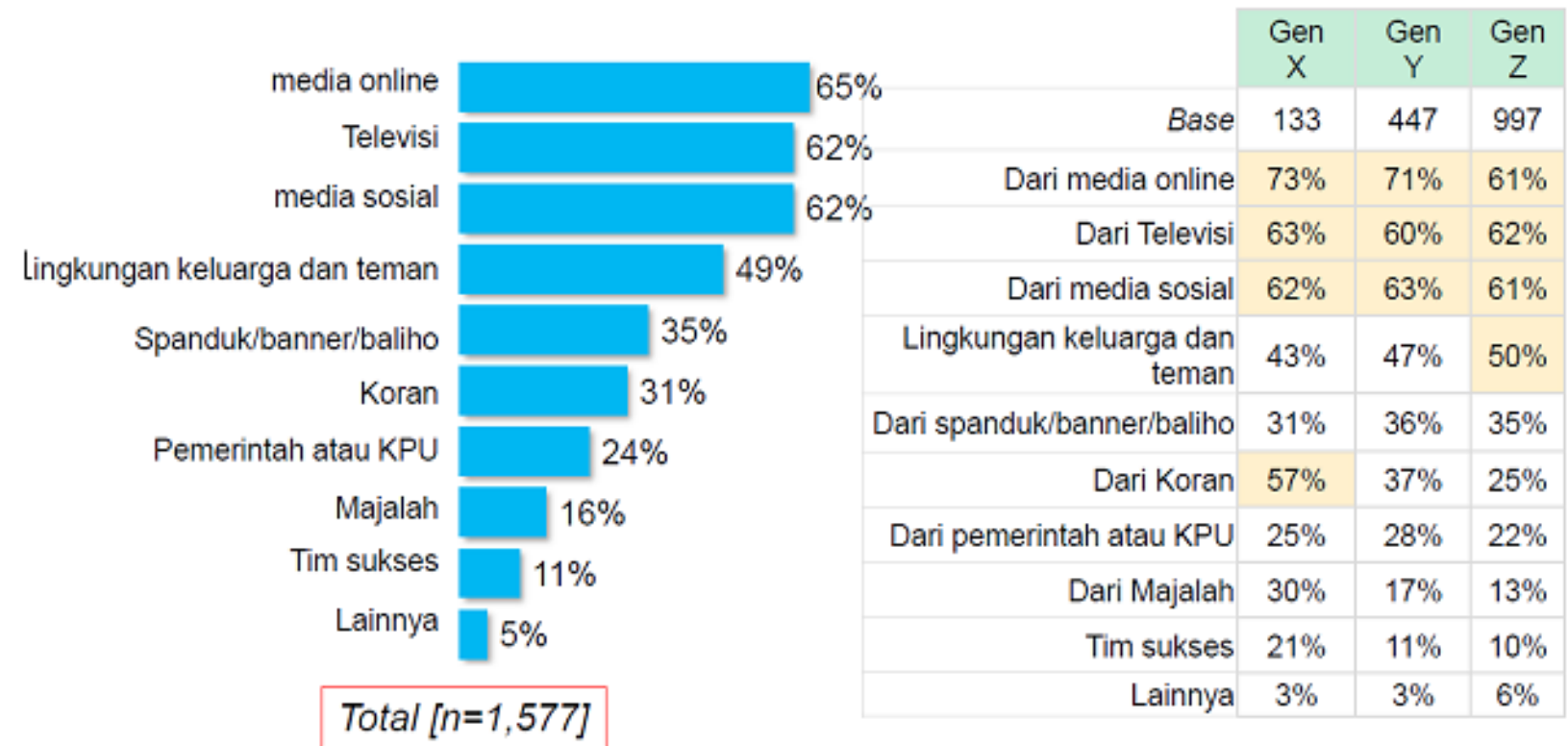

Sumber: analisis Femina, 2018

\section{Gambar 3 Media yang Digunakan dalam Memperoleh Informasi}

Namun pada Gambar 3 terlihat jelas bagaimana mereka mendapatkan informasi tentang calon pemimpin mereka. Media online, televisi, dan media sosial merupakan pilihan terbanyak dari para responden (di atas 60\%), sedangkan keluarga hanya hampir setengah dari responden, diikuti oleh spanduk/banner/baliho, dan koran (kurang lebih 30\%). Sedangkan koran lebih besar diakses oleh Generasi X (57\%) dibandingkan dengan Generasi Y (37\%) dan Y (29\%).

Temuan di atas sangat berbeda dengan penelitian mengenai sumber informasi pada masa pemilihan politik sebelumnya yang menunjukkan bahwa hampir setengah responden masih mengandalkan media massa konvensional sebagai sumber utama berita atau isu politik Indonesia (Wibowo \& Mirawati, 2013). Bahkan mereka yang menggunakan situs Internet dan media sosial sebagai sumber berita tetap saja mencari validitas berita yang mereka dapatkan dengan menonton televisi atau mencarinya di surat kabar. Perilaku tersebut juga mendukung temuan bahwa lebih dari setengah 
responden ragu-ragu, tidak sepenuhnya percaya terhadap ucapan tokoh politik dan tokoh muda yang mereka ikuti Twitter-nya. Mereka yang mengikuti akun Twitter tokoh politik mengaku bahwa mereka tidak mengidolakan para tokoh tersebut, mereka mengikuti untuk sekadar ingin tahu pandangan sang tokoh. Bahkan, terkadang mereka tak segan membantah bila punya pandangan yang berbeda.

Pemahaman cara berkomunikasi memang tampak sebagai hambatan utama dalam berkegiatan politik. Hal ini ditekankan dalam penelitian Kusuma (2014), bahwa kampanye persuasif dalam politik kontemporer di media sosial seharusnya mengandalkan tiga teknik yang membentuk jenis-jenis komunikasi yang relevan dengan opini publik. Pertama, karena persuasi adalah proses dua arah, timbal-balik, persuader harus menyesuaikan imbauannya dengan titik pandang pendengar karena "khalayak memilih komunikasi yang oleh mereka dianggap paling menyenangkan". Untuk melakukan hal itu persuader mengumpulkan keterangan mengenai apa yang menyenangkan bagi anggota kelompok melalui teknik polling. Kedua, karena persuasi adalah proses satukepada-banyak dan juga satu-kepada-satu, persuader menggunakan teknologi yang tepat untuk menyebarkan pesan kepada anggota kelompok (dalam kasus propaganda), perseorangan (dalam kasus periklanan massal), atau kolaborator yang potensial (dalam kasus retorika). Hal ini melibatkan pilihan antara teknologi lisan, cetakan, dan elektronik, antara penampilan pribadi, surat kabar atau majalah, dan radio, televisi, Internet sebagai media. Ketiga, persuader memilih sarana dan gaya linguistik yang tepat untuk menuangkan propaganda, periklanan, dan retorikanya.

Terkait perolehan informasi tentang calon pemimpin dari pemerintah dan Komisi Pemilihan Umum hanya seperempat responden (24\%). Padahal sudah cukup lama dikatakan bahwa peranan KPU sangat penting dalam memberikan informasi. Seperti yang disampaikan dalam penelitian yang dilakukan oleh Yusuf (2010) bahwa sosialisasi politik, khususnya tentang pemilu sangat penting dilakukan agar penyelenggaraan Pemilu dari waktu ke waktu semakin berkualitas. Lanjut Yusuf, bagaimanapun juga pemilu telah menjadi harga mati sebagai mekanisme untuk menghasilkan pemerintahan yang demokratis, dan dengan sendirinya sosialisasi politik yang berhasil dengan baik akan mendukung pemilu menjadi lebih baik. Pengalaman pemilupemilu sebelumnya ataupun pemilu Kepala Daerah di berbagai daerah di Indonesia harus menjadi pelajaran tentang bagaimana harus menyelenggarakan pemilu dengan lebih baik.

Di samping itu, berdasarkan wawancara dengan nara sumber KPU Biro Teknis dan Hubungan Partisipasi Masyarakat, kegiatan KPU terkait perempuan cukup beragam. Kegiatan-kegiatan KPU dalam rangka meningkatkan partisipasi masyarakat untuk Pemilih Perempuan antara lain sebagai berikut: (a) sosialisasi bersama Himpunan Wanita Penyandang Cacat Indonesia, yaitu sosialisasi rutin kepada wanita penyandang disabilitas di beberapa daerah di Indonesia; (b) Menyampaikan hak-hak dan kesempatan para disabilitas untuk hak pilih dan penggunaannya; (c) Dalam pendidikan diadakan Lomba Cerdas Cermat, yang sepenuhnya melibatkan peserta ibu-ibu dengan materi lomba tentang kepemiluan; (d) KPU Goes to Campus and School, yaitu menyelenggarakan sosialisasi di beberapa kampus, bekerja sama dengan Rektorat dan Badan Eksekutif Mahasiswa (BEM), dengan memprioritaskan kursi untuk Pemilih muda perempuan sebagai peserta. Kegiatan ini telah dilaksanakan di kampuskampus di Aceh, Malang, Makassar, Sumatera Utara, dan rencana berikutnya untuk awal 2019 di Jogja, yaitu Universitas Gadjah Mada. Sementara itu, KPU tingkat Daerah Provinsi dan/atau Kabupaten/Kota terjun ke sekolahsekolah tingkat Sekolah Menengah Atas (SMA) untuk mendekati para pemilih pemula. Contoh lainnya, mereka juga melakukan Pendidikan Pemilih Pekerja Komersial dengan melakukan kunjungan ke daerah yang banyak ditempati Pekerja Komersial. Kegiatan Utama di lokasi tersebut adalah mengadakan diskusi interaktif dan tanya jawab mengenai pentingnya memilih. Selain itu, lomba Kuliner Pemilu di beberapa kelurahan, yaitu lomba kuliner seperti membuat tumpeng kreatif dengan Tema Pemilu yang sepenuhnya hanya melibatkan peserta ibu-ibu.

Bila menilik kegiatan-kegiatan tersebut di atas, sepertinya memang difokuskan atau diarahkan pada kegiatan di daerah-daerah yang bukan bersifat kota-kota utama. Padahal berdasarkan responden penelitian ini, sebagian besar merupakan pemilih mula atau berulang 
dari golongan menengah ke atas, yang memiliki kemungkinan lebih tinggi berpendapat secara individual dibandingkan pemilih primordial atau yang masih terpengaruh oleh agama. Berdasarkan konfirmasi dengan pihak KPU, memang tidak ada evaluasi atau pengukuran terhadap efektivitas kampanye komunikasi yang dijalankan.

Selain itu, hasil penelitian juga menunjukkan bahwa ternyata tim sukses bukan menjadi referensi utama para pemilih perempuan, karena hanya $11 \%$ untuk semua generasi dari responden yang mengetahui tentang calon pilihan dari para pelaku politik tersebut. Dengan demikian dapat dikatakan bahwa rasa keingintahuan generasi pemilih mula ini tidak dijawab oleh para calon pemimpin. Misalkan, rata-rata mereka hanya memasang baliho foto, tapi tidak ada informasi pendukung lain tentang mengapa mereka harus memilih kandidat tersebut. Dapat pula dimungkinkan bahwa tidak banyak juga kandidat pemimpin yang memaksimalkan penggunaan media sosial dengan baik, misal konten media sosial mereka masih belum relevan dengan apa yang mereka lakukan.

Padahal pada tahun 2005 sudah terdapat arahan atau kiat-kiat "9 Kunci Sukses Tim Sukses PILKADA Langsung" yang berisi antara lain: (i) menawarkan visi, misi, strategi, kebijakan dan program kerja yang sederhana dan menyentuh kepentingan masyarakat 'akar rumput'; (ii) menjalankan soft dan hard campaign yang efektif dan efisien, dan paham karakteristik pemilih dan lakukan komunikasi sambung rasa. Hal ini sebenarnya sangat disayangkan karena informasi terkait para calon pemimpin sangat signifikan dalam menentukan pilihan (Herry, 2005)

Dari hasil FGD, narasumber dari Komunitas Peduli menegaskan bahwa media sosial itu menjadi alat ampuh di kalangan generasi muda, di mana Line dan Instagram menjadi pilihan popular. Untuk materi, nara sumber dari Sekretariat Koalisi Nasional Indonesia mengatakan bahwa agar Role model merebut pengaruh, maka diperlukan upaya dalam memberikan output dan outcome yang perspektif gender. Terkait hal itu, sebagian perempuan merasa bahwa keterwakilan perempuan belum memuaskan karena mereka adalah selebriti, terkait dinasti uang, dan tidak fokus pada substansi memperjuangkan kepentingan perempuan. Hal inipun ditambahkan dari perwakilan Sekretariat Koalisi Nasional Indonesia sebagai berikut:

Kita selalu berusaha dari tahun 2005 sampai hari ini, dalam konteks pilkada, PILKADA/PEMILU meng-encourage para perempuan di desa untuk memilih sesuai dengan keinginannya, dan yang benar-benar mendukung program-program kesejahteraan. Tapi belum pada tahapan wanita yang menjadi pemimpin.

Komisi Perempuan Indonesia (KPI) menyatakan saat FGD bahwa mereka mendorong agar pemimpin perempuan mengajukan program yang minimal terkait kepentingan perempuan. Akan tetapi pada faktanya adalah sebagai berikut:

Memang di beberapa tempat kami mendorong bagaimana pemimpin perempuan mengajukan program, minimal yang terkait kepentingan perempuan. Di beberapa tempat juga ada banyak kandidat yang mendatangi KPI, karena dianggap ini organisasi perempuan, punya basis masa, punya kader di desa-desa sehingga penting untuk diajak kerjasama. Namun pada faktanya memang tidak ada program yang diajukan ada untuk perempuan.

Permasalahan tersebut juga disampaikan oleh Koalisi Perempuan (KP). KP pernah mengajukan, misalnya program kesehatan perempuan yang tidak tercakup dalam Jaminan Kesehatan Nasional:

Kita ajukan untuk kesehatan perempuan, tapi pada faktanya itu seperti suara yang tidak nyaring didengar, kecil sekali. Atau misalnya Raskin dan program bantuan sosial lainnya itu tetap dipandang sebagai program bantuan. Bukan sebagai hak warga negara, dimana dia punya kewajiban untuk memenuhi hak warga negara.

Lanjutnya, yang menjadi permasalahan utama adalah sumber terdekat, di mana para pemilih pemula masih diatur oleh keluarga, dan bahkan perempuan itu menggunakan hak pilihnya atau tidak. Nara sumber KPmenekankan bahwa dengan adanya data bertambahnya pemilih perempuan apakah pilihannya datang dari dirinya sendiri dan kesadarannya, atau perpanjangan pilihan suaminya. Contohnya: 


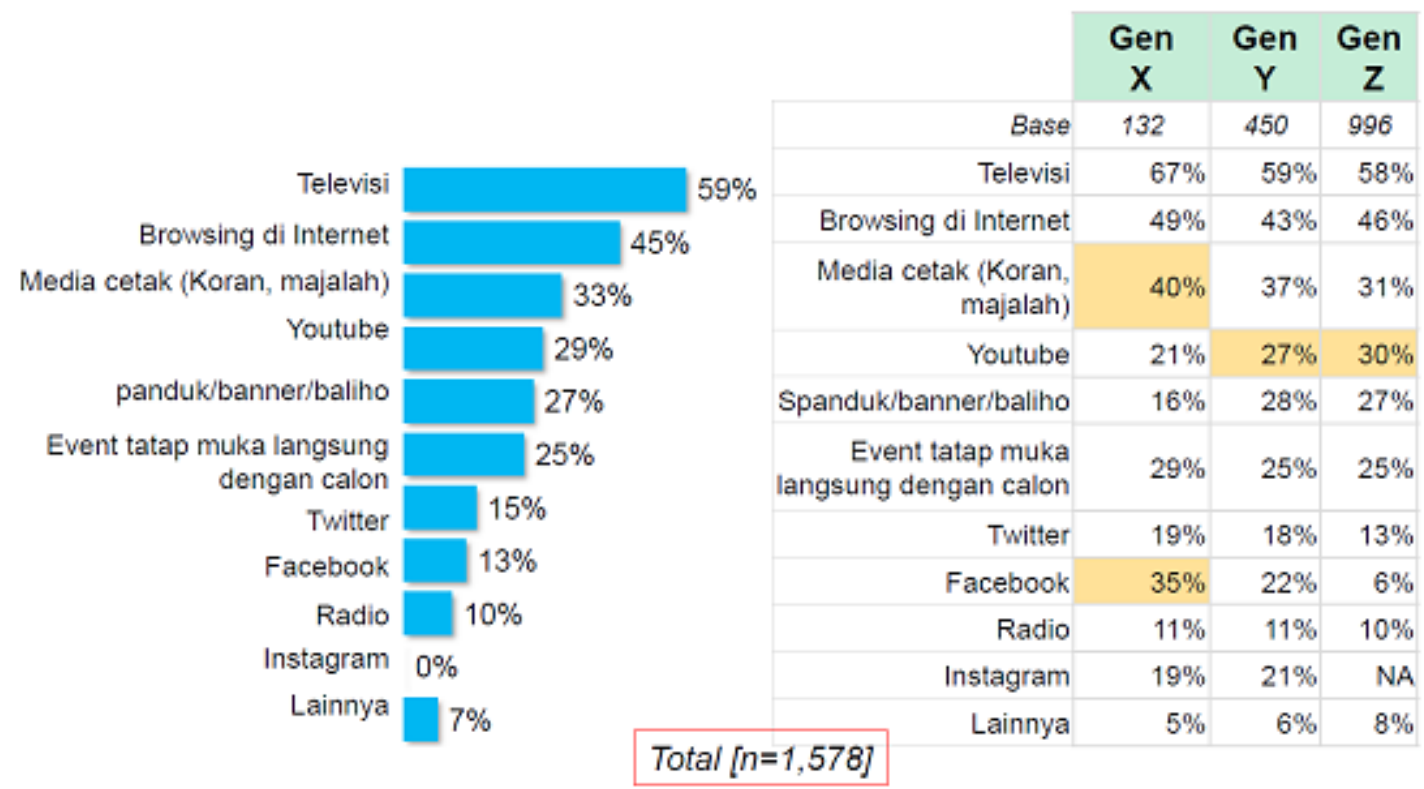

Sumber: analisis Femina, 2018

\section{Gambar 4 Media Kampanye yang Paling Menarik}

Saya ada teman yang bekerja di media. Dia tidak datang untuk mencoblos. Katanya bagi dia itu tidak menarik. Tetapi ketika saya telusuri lagi, ternyata suaminya Golput jadi dia mendapat pengaruh dari suaminya untuk tidak memilih. Teman saya satu lagi, malah berpikir untuk memilih yang Muslim saja karena suami mengatakan itu. Padahal sebetulnya dia sadar dan merupakan pendukung orang-orang yang kinerja baik.

Dengan adanya beberapa contoh yang menjadi alasan untuk tidak memilih atau bersifat subyektif, dan tidak menjadi acuan utama, apakah media kampanye dapat memberikan daya tarik tersendiri tentang calon pemimpin? Berdasarkan hasil penelitian, sebagian besar responden masih melihat televisi sebagai media untuk melihat kampanye dibandingkan media sosial. Bahkan event tatap muka bukan lima pilihan teratas.

Pada Gambar 4 dapat dikatakan bahwa sebaran penggunaan media untuk melihat kampanye sangat beragam, termasuk preferensi dari tiap generasi, walau televisi merupakan prioritas bagi ketiga generasi tersebut. Dengan demikian, bila dianalisis, maka sumber informasi untuk memperkenalkan calon pemimpin sebaiknya memanfaatkan televisi dan materi on-line dan peningkatan informasi dari calon pemimpin sendiri, dan sumber terdekat, terutama tim sukses. Bila dalam penelitian ini perolehan informasi lebih mengandalkan sosial media, ternyata untuk kampanye lebih mengandalkan televisi.

Hal ini terkait dengan penelitian Wibowo \& Mirawati (2013) juga, yang menunjukkan bahwa pandangan rakyat Indonesia tentang kondisi politik Indonesia yang masih sangat dipengaruhi oleh media massa konvensional. Wibowo \& Mirawati memberikan saran bagi para praktisi media untuk menjadikan televisi sebagai penggerak ke arah Indonesia yang lebih baik, di antaranya dengan merancang programprogram yang berisi pemberian semangat atau optimisme tentang masa depan Indonesia, termasuk kondisi politik Indonesia ke depan yang akan lebih baik dengan partisipasi generasi muda. Selain itu, sebagaimana saran dari Gilang, Parahita, dan Puspitasari (2014) pemanfaatan dari web untuk menginformasi, memobilisasi, menghubungkan, dan melibatkan harus dilaksanakan. Pada pemilihan 2014, Gilang, Parahita dan Puspitasari (2014) juga menyatakan bahwa tidak ada upaya untuk mengoptimalkan penggunaan web saat masa kampanye, dengan alasan menggunakan media sosial untuk menghubungkan dan melibatkan konstituensinya. Namun ternyata tidak memberi kepastian bahwa interaksi terjadi antara partai politik atau kandidat dengan netizen. Dengan demikian web atau media sosial lebih cocok bila telah terjadi hubungan. 
Dengan mendapatkan data-data kuantitatif yang tertera pada Gambar 2, Gambar 3, dan Gambar 4 yang menunjukkan masing-masing untuk pemahaman responden, perolehan informasi, dan kampanye, dan dibandingkan dengan minat politik berdasarkan sumbu analisis. Diadopsi dari tulisan Waugh (2011) tentang penelitian dari Universitas Princeton yang bereksperimen terhadap perilaku kelompok, maka disusun matriks berikut: (X) minat (interested) - tidak berminat (ignorant) dan (Y) untuk terinformasi - tidak terinformasi. Dengan demikian, dapat dibuat analysis matriks terkait dengan variabel serapan informasi dan minat keterlibatan politik. Sumbu analisis yang ditentukan oleh Accenture adalah berdasarkan tingkat informasi yang diketahui berdasarkan minat pada politik. Masing-masing sumbu menunjukan empat karakteristik sikap pada pemilihan calon pemimpin, yaitu: activist, passivist, pessimist, dan apathetic.

Penjelasan mengenai matriks tersebut adalah sebagai berikut: Activist - merupakan karakteristik bila para pemilih memiliki informasi, dan memiliki minat pada pemilihan suara. Ini adalah kondisi paling ideal atas sikap pemilih. Karakteristik berikutnya adalah pessimist, yaitu bila para pemilih memiliki informasi yang baik, namun memilih untuk tidak memperhatikan (ignorant). Sedangkan karakteristik tipe apathetic adalah bila para pemilih tidak memiliki informasi yang tepat, namun memiliki ketertarikan. Tipe ini bukan apatis, karena bila apatis berarti tidak memiliki ketertarikan. Terakhir adalah passivist, yaitu bila para pemilih tidak mendapatkan informasi dan tidak memiliki minat partisipasi.

Data yang terdapat pada Gambar 1 menunjukkan bahwa suara perempuan dapat diperhitungkan dan tidak dapat diabaikan. Perilaku Generasi $\mathrm{X}+\mathrm{Y}$ dengan Generasi $\mathrm{Z}$ berbeda walautidak signifikan. Namun minat dari Generasi Z lebih tinggi dalam memahami calon pemimpinnya. Jadi secara prinsip, para pemilih yang memiliki sikap apathetic merupakan mereka yang memiliki untuk menjadi activist karena mereka sudah terinformasi mengenai pemimpin prospektif mereka, sehingga mudah untuk dapat dibentuk pemahamannya. Sedangkan mereka yang pesimis - walau pada responden ini hanya sedikit - sudah terinformasi dengan baik. Sehingga bila mendapat atau diberikan tambahan pengetahuan agar mereka lebih berminat, maka akan mudah untuk menjadi activist. Sedangkan untuk mereka yang passivist akan lebih baik baik diarahkan untuk menjadi apathetic agar minatnya terbentuk, karena pada prinsipnya informasi yang mereka miliki dapat dikelola untuk mendorong dalam upata memberikan minat. Dalam hal minat antar generasi, pemilih generasi millennials ( $Y$ and $Z$ )memiliki minat politik yang lebih tinggi. Mereka tidak takut untuk berujar dan mengekspresikan pendapat mereka. Sedangkan Generasi X lebih tidak memperhatikan karena mereka telah mengalami pemilihan sebelumnya dan memiliki pengalaman yang berbeda sehingga memungkinkan memiliki perspektif yang berbeda sebagaimana disampaikan di atas.

Dari analisis matriks tersebut, juga terlihat adanya pemilih yang belum memiliki akses dan ketersediaan informasi terkait pilihan politik mereka. Hal ini dapat membuat para pemilih enggan untuk menyalurkan aspirasinya dalam ajang demokrasi elektoral. Bila dikaitkan dengan perolehan informasi politik (pada Gambar 3), bahwa tidak sedikit dari golongan informed ini mendapatkan informasinya dari media sosial, yang tentu saja belum teruji atau terverifikasi kebenarannya.

Pada penelitian Lea, Spears \& Watt (2007) menunjukkan bahwa visibilitas meningkatkan ketertarikan atau peminatan, dan kohesivitas bagi kelompok yang mendapatkan penggambaran. Dengan demikian, relevan dengan penelitian ini, kemampuan dari para pemilih perempuan dapat ditingkatkan agar lebih melek politik dan tidak mudah diarahkan untuk kepentingan partai atau individu tertentu dengan memberikan gambaran menggunakan visibilitas. Maka, harus ada usaha untuk melakukan verifikasi sebagai pemilih dalam menentukan pemimpin pilihannya. Termasuk memeriksa apakah visi dan misi dari partai atau pemimpin sesuai dengan prinsipnya.

Sebetulnya terdapat upaya dari partai politik untuk menyampaikan informasi, yang akhirnya dapat mempengaruhi para calon pemilihnya. Penelitian terhadap Dewan Perwakilan Wilayah Partai Keadilan Sosial (DWP PKS) di Jawa Barat menunjukkan bahwa pentingnya keragaman media komunikasi dalam berinteraksi dengan para pendukung atau calon pendukungnya (Nurussaadah \& Sumartias, 2017). Komunikasi politik yang berlangsung dalam keterbukaan ideologi DPW PKS Jawa Barat melibatkan 


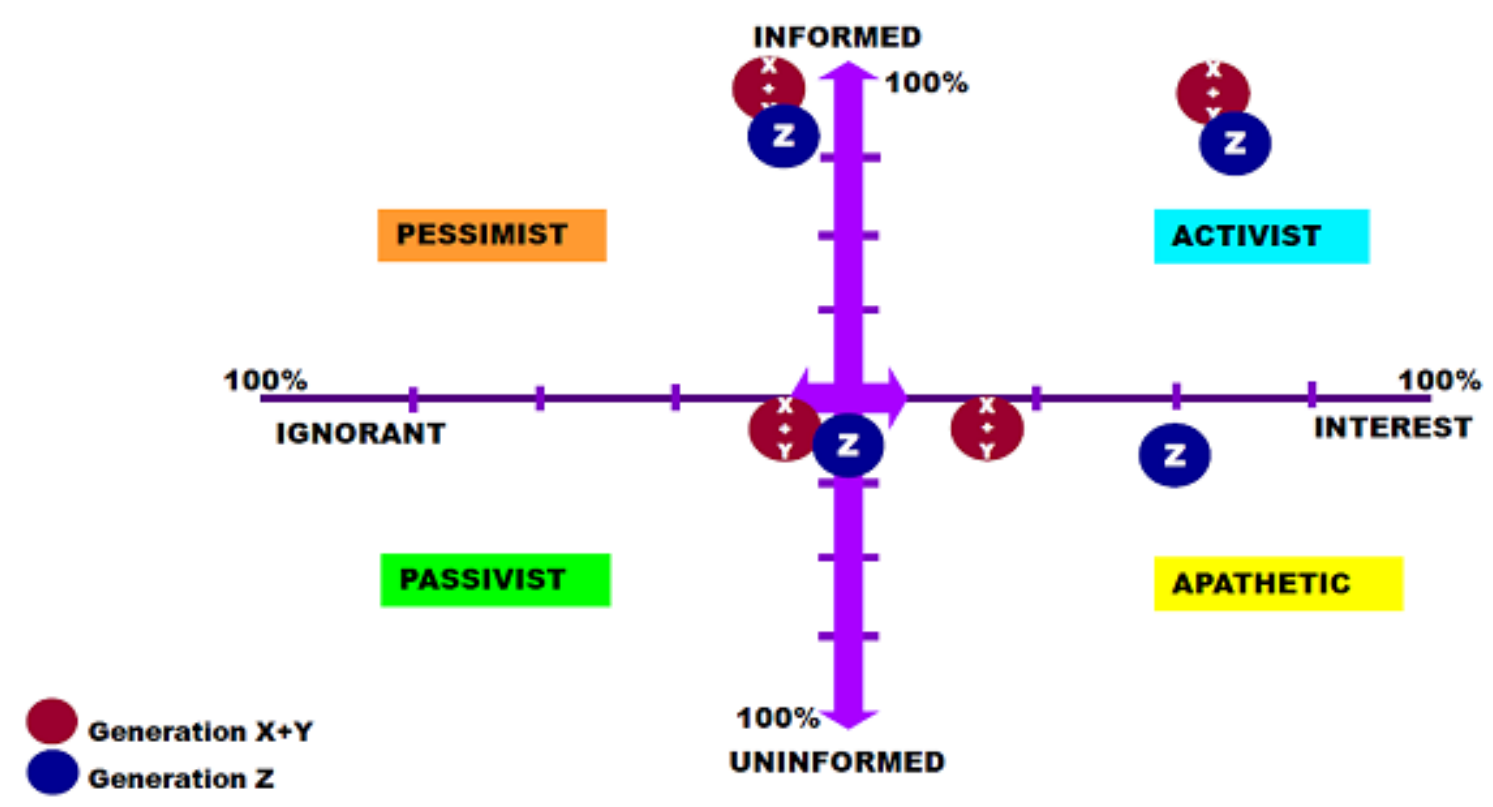

Sumber: Analisis Accenture Indonesia, (Pratiwi, 2018)

\section{Gambar 2 Analisis Matriks}

komunikator-komunikator politik dari dalam dan luar PKS. Selain itu, komunikasi juga melibatkan kader, simpatisan, masyarakat Jawa Barat serta tamu undangan sebagai komunikannya. Komunikasi politik yang terjadi dalam keterbukaan ideologi melalui pesan verbal dan nonverbal yang disampaikan dalam beberapa kegiatan DPW PKS Jawa Barat seperti; Muswil, Rakerwil dan Rakorwil. Komunikasi politik dalam keterbukaan ideologi DPW PKS Jawa Barat terjadi melalui pola komunikasi organisasi, dengan penyampaian pesan berupa pidato serta arahan. Komunikasi politik ini merupakan bagian dari bentuk penyampaian pesan keterbukaan ideologi DPW PKS Jawa Barat dari pimpinan kepada yang dipimpin. Selain itu, komunikasi merupakan bagian dari strategi politik untuk membangun citra partai yang inklusif dan menghilangkan citra partai yang eksklusif, menghilangkan stigma miring (stereotype) di masyarakat, membangun kerja sama dengan semua elemen bangsa, mendapat tempat di hati masyarakat, terciptanya kawasan baldatun toyyibatun warobbun ghofur, implememtasi slogan berkhimad untuk rakyat (pelayanan, pemberdayaan dan pembelaan) yang semuanya merupakan bagian dari tujuan dakwah secara umum dan tujuan politik secara khusus yang menunjukkan bentuk-bentuk komunikasi dari retorika, propaganda, public relations, pelaksanaan kampanye politik, dan lobi-lobi atau negosiasi politik.

Ilmuwan bidang politik Robert Erikson, Michael Mackuen dan James Stimson (Illing, 2017), menyatakan bahwa para pemilih yang berupa agregasi kolektif akan bertindak dengan suatu tujuan dan dapat diprediksi, walau secara individu akan tidak kelihatan. Jadi idenya adalah mendapatkan mayoritas pemilih yang signifikan memiliki rasa ingin tahu dan tidak terinformasi, yang akhirnya saling bertukar pandangan.

Dorongan untuk terjadinya pemungutan suara yang berhasil adalah dengan arahan yang intelek ke pemilih minoritas yang berpendidikan dan memiliki minat. Hal ini dapat dilakukan terhadap para apathetic.

\section{SIMPULAN}

Hasil riset ini menunjukkan bahwa sosialisasi dari para pemerintah maupun politisi yang menjadi calon pemimpin atau pendukung calon pemimpin (antara lain tim sukses) memberi persepsi yang baik dengan adanya informasi dan kegiatan yang terpapar melalui berbagai media: on-line, sosial, dan televisi. Dapat dikatakan bahwa ketiga saluran tersebut yang menentukan preferensi untuk memilih. Media komunikasi lain yang dipergunakan oleh pemilih adalah media cetak (generasi X) dan Youtube (generasi $\mathrm{Y}+\mathrm{Z}$ ), walau pada intinya beragam dan saling melengkapi dalam hal 
generasi.

Pemahaman terhadap setiap karakteristik sikap dari para pemilih dan calon pemilih penting untuk menentukan informasi apa yang akan disampaikan mengenai calon pemimpin, sehingga pilihan tidak sekedar berdasarkan budaya primordial dan agama, namun terkait dengan program yang relevan, terutama yang mendorong pada pemberdayaan perempuan. Hal lain yang mendorong partisipasi dan pemahaman tentang politik adalah terkait dengan dialog politik yang dikatakan akan lebih kohesif bila merupakan kelompok dalam skala kecil. Dengan meningkatnya pengalaman layar kedua dalam jumlah signifikan, maka media dengan respon tercepat, yang memberikan kesempatan dalam menghubungkan diri mereka dengan para politisi mendekati 'real-time' adalah yang berjaya.

Saran ilmiah untuk penelitian selanjutnya adalah mendalami pemahaman atas apa yang diketahui oleh para pemilih perempuan terhadap calon pemimpin mereka dengan menggali melalui wawancara kepada beragam generasi yang menjadi acuan dalam penelitian ini. Sedangkan saran praktis adalah bagi KPU dan tim sukses untuk memperhatikan pentingnya edukasi yang tepat bagi para calon pemilih, terutama dalam hal ini kaum perempuan dengan memberikan gambaran yang dapat mendukung visibilitas kandidat.

\section{DAFTAR PUSTAKA}

Achen, C. H., Bartels, L.M. (2017). Democracy for realists: why elections do not produce responsive government, New Jersey, United States: Princeton University Press.

Broide, M. (1998). Having a voice in politics. in Lesley's Handbook of Public Relations and Communications. $5^{\text {th }}$ Edition. Chicago: NTC.

Bryman, A. (2016). Social research methods. $5^{\text {th }}$ Edition. United Kingdom: Oxford University Press.

Eriyanto. (2014). Analisis jaringan komunikasi. Jakarta: Kencana.

Evins, S. (2016). Social media and the rise of the connected voters. Political Communication in Real Time: Theoretical and Applied Research Approaches. Ed. Schill, D., Rika, K.\& Jasperson A.E. New York: Routledge Studies in Global Information, Politics and
Society.

Gilang, A., Parahita, D., \& Puspitasari, N. A. (2014). Political parties re-disconnected? websites and social media of Indonesian political parties. Interact, 3(1), 15-32.

Herry, A. (2005). 9 Kunci sukses tim sukses pilkada langsung. Yogyakarta: Galang Press.

Ihsanuddin. (2018). Partisipasi pemilih pilkada serentak 2018 capai 73,24\%. Diakses dari https://nasional.kompas. $\mathrm{com} / \mathrm{read} / 2018 / 06 / 29 / 21115801 /$ partisipasi-pemilih-pilkada-serentak-2018capai-7324-\%. 29 Juni 2018, Diakses 10 Juli 2018.

Illing, S. (2017). Two eminent political scientists: the problem with democracy is voters - why almost everything you think about democracy is wrong. Diakses dari https://www.vox.com/policy-andpolitics/2017/6/1/15515820/donald-trumpdemocracy-brexit-2016-election-europe Updated Jun 24, 2017, 12:12pm 20 Juni, 2018.

Kusuma, S. (2014). Komunikasi politik di komunitas virtual. Jurnal Interact Vol. 3, No. 1, Mei 2014 Hal. 43-54. Diakses dari http://ojs.atmajaya.ac.id/index.php/ fiabikom/article/view/717/577.

Lea, M., Spears, R., \& Watt, S. E. (2007). Visibility and anonymity effects on attraction and group cohesiveness. European Journal of Social Psychology. 37, 761-773 (2007) DOI: 10.1002/ejsp.398.

Nadlir, M. (2018). KPU rilis DPT final untuk pilkada serentak 2018. Diakses dari https://nasional.kompas.com/ $\mathrm{read} / 2018 / 05 / 25 / 23364141 / \mathrm{kpu}-$ rilis-dptfinal-untuk-pilkada-serentak-2018. $25 \mathrm{Mei}$ 2018.

Nee, R. C., Shen, H, \& Dozier, D., M. (2017). Double vision: testing audience effects of competing social media and institutional media political framing. AEJMC. Vol 11, Issue 4, 2017pp. 211-228. Diakses dari https://doi. org/10.1177/1931243117690426.

Nurussaadah, E., \& Sumartias, S. (2017). Komunikasi politik PKS dalam keterbukaan ideologi. Jurnal Kajian Komunikasi. Diakses dari https://doi.org/10.24198/jkk. v5i1.8522. 
Perloff, R. M. (2010). Dynamics of persuasion, the: communication and attitudes in the 21 st century.

Perloff, R. M. (2015). Mass communication research at the crossroads: definitional issues and theoretical directions for mass and political communication scholarship in an age of online media. Mass Communication and Society, 18(5), 531556. Diakses dari https://doi.org/10.1080/1 5205436.2014 .946997$.

Pratiwi, Y. (2018). Faktanya, wanita makin rasional dalam memilih calon pemimpin. Diakses 3 Agustus 2018 dari http://www. femina.co.id/trending-topic/faktanyawanita-makin-rasional-dalam-memilihcalon-pemimpin. Ditulis 25 Jun 2018.

Samosir, H. (2014). Kesetaraan gender: pendidikan politik penting bagi perempuan. Diakses dari CNN Indonesia 13/11/2014 05:14 WIB https://www.cnnindonesia. com/nasional/20141112210146-20-11163/ pendidikan-politik-penting-bagiperempuan 11 Agustus, 2018.

Schill, D., \& Kirk, R. (2014). Courting the swing voter: "real time" insights into the 2008 and 2012 U.S. Presidential debates. American Behavioral Scientist, 58(4), 536-555. Diakses dari https://doi. org/10.1177/0002764213506204.

Setiawan, S. R. D. (2018). Tumbangkan gus ipul-puti di jatim, ini rahasia kekuatan khofifah. Diakses 07.06 WIB 2 Agustus, 2018 dari https://nasional.kompas.com/ $\mathrm{read} / 2018 / 06 / 28 / 07060761 /$ tumbangkangus-ipul-puti-di-jatim-ini-rahasiakekuatan-khofifah-emil.28/06/2018,

UNDP. (2016). Gender inequality index human development report. Diakses 2 Agustus, 2018 dari http://hdr.undp.org/en/ composite/GII.

Waugh, R. (2018). Vote for apathy? The uninformed are the key ingredient for a working democracy, study finds. Diakses 20 Juni, 2018 dari http://www.dailymail. co.uk/sciencetech/article-2076026/Theuninformed-essential-working-democracystudy-finds.html. Updated: 18:31 BST, 19 December 2011.

Wibowo, K. A., \& Mirawati, I. (2013). Realitas politik Indonesia dalam kacamata pengguna Twitter. Jurnal Kajian Komunikasi, 1/1, 1117. Diakses dari https://doi.org/10.24198/ jkk.v1i1.6027.

World Economic Forum. (2016). The global gender gap report - Insight Report.

Yusuf A., R., M. (2010). Peran Komisi Pemilihan Umum (KPU) dalam pendidikan politik. Ganeç Swara. Vol. 4 No.1 Februari 2010. Hal 13-16. Diakses dari http:// unmasmataram.ac.id/wp/wp-content/ uploads/3.-M.-Yusuf-A.R.pdf. 